\title{
To Borrow or not to Borrow? Some Remarks on vaibhavīyanarasiṃhakalpa of Sätvatasaṃhitā
}

\author{
Ewa Dębicka-Borek
}

Published online: 20 August 2014

(C) The Author(s) 2014. This article is published with open access at Springerlink.com

\begin{abstract}
Some remarks on the possible methods of composing samhitās as hinted in chosen texts belonging to the Pāñcarātra school are presented in Sect. 1. In Sect. 2, the content and the structure of the Sätvatasamhitā and Íśvarasamhitā are compared. In fact, both texts are independent works even though in the light of some Pāñcarātrika texts they are considered to be mutually linked, the latter being considered a "commentary" of the former. In Sect. 3, the initiation $(d \bar{\imath} k s ̦ \bar{a})$ as found in both texts is outlined. In Sect. 4, I focus on the re-use of the portions concerning $d \bar{i} k s \bar{a}$ : although the redactor of the Ísvarasamhitā borrowed almost all the Sātvatasamhitāa's chapters on initiation, he dealt in a very different way with the practice called vaibhaviyanarasimhakalpa that in the context of the latter text plays the role of a unique preliminary purification. Strikingly, the Sātvatasamhitā's redactor reused the initial verses describing the vaibhaviyanarasimhakalpa, putting them into other contexts, not necessarily connected to the issue of initiation, whereas he totally omitted its impressive section concerning magical powers (siddhi).
\end{abstract}

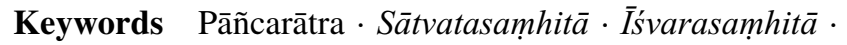
vaibhavìyanarasimhakalpa . Initiation · Textual re-use

The constant re-using of texts seems to be one of the most characteristic features of the literature of Vaiṣnava Pāñcarātra.

First traces of the Pāñcarātra doctrine can be found already in the Nārāyāniya section of Mahābhärata. However, in the opinion of Sanderson (2001, p. 38), the form in which its most important texts, called the "three gems" (ratnatraya), i.e. Jayākhyasaṃhitā (JayS), Sãtvatasaṃhitā (SātS) and Pauṣkarasaṃhitā (PaușS), were preserved is a result of the reformation of the Pāñcarātra ritual under the influence of

E. Dębicka-Borek ( $\bowtie)$

Jagiellonian University, Kraków, Poland

e-mail: debicka.debicka@uj.edu.pl 
the Kashmirian Śaiva mantramārga. In such circumstances, these three texts must have been composed around the middle of the ninth century in Kashmir. On the contrary, the younger samhitās of Pāñcarātra were most probably composed in the South of India. Due to the coexistence with South Indian brahmanical circles, the teachings they contain took a more orthodox shape approved by teachers of the Śrivaiṣnava tradition. These are also the texts which gave the basis for the order of worship in South-Indian Śrivvaiṣnava temples. Among them one can enumerate the texts believed by tradition to be specific commentaries (vyākhyā) of the oldest "three

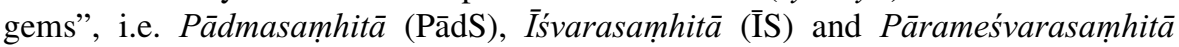
(PārS), as well as other relatively important samhitās.

That the textual borrowings happened to a great extent within the boundaries of the Pāñcarātra tradition has already been shown in the research done by Rastelli (2006) on the basis of PārS, which, so far, seems to be the best example of a text being itself a kind of compilation of the passages taken over from other sources, usually the most respected saṃhitās of Pāñcarātra, the already mentioned "three gems".

However, Sanderson (2001, pp. 1, 37-39) has shown that there are also extensive parallel passages linking the Tantric Śaiva and Pāñcarātrika sources, proving, therefore, that there was also a movement from Pāñcarātrika literature toward Śaiva. This is evident in the case of the Śaivasiddhānta text Bṛhatkālottara, which in terms of the accounts of cremating initiates (antyești) and śraddhā ceremonies draws richly from two chapters of JayS. The Śaiva redactor did not avoid some inconsistencies although he obviously attempted to eliminate the traces of the Vaiṣnava material.

Another example, again examined by Rastelli (2007), comes from Agnipurāna. Among passages hailing from other sources, for example from the Śaivasiddhānta text entitled Somaśambhupaddhati (AP 72-90, 92-103), there are also those (AP 21-70) deriving, sometimes verbatim, sometimes with regard to the contents, from Pāñcarātra saṃhitās, mostly from Hayaśírșapañcarātra and Nāradīyasaṃhitā.

The focus of the present paper will be to analyze, in turn, a particular portion of the $\overline{\mathrm{I} S}$ which is perceived by the tradition as a specific commentary upon SătS. At least in regard to the initiatory prescriptions, the former draws richly from the latter; however, the process is quite selective. My attempt will be, therefore, to discuss the possible reasons behind such a selection. Many questions arise in this connection. Is it at all meaningful that the compiler of the $\overline{\mathrm{I} S}$ avoided the coherent passage on vaibhavīyanarasimhakalpa, which, judging from its size (457 ślokas), was quite important for the SātS's initiatory system? One might say that there is no need to look for further explanations since there are many other portions of SātS neglected by the compiler of the İS. Yet, despite the negligence of vaibhaviyanarasimhakalpa as a coherent section, there are single verses derived from it dispersed throughout many chapters of ISS, which suggests that its compiler was familiar with it. Hence, the absence of the section as a consistent unit needs a specific explanation.

In order to give some arguments for the alleged purposefulness of the treatment (or rather: the lack of treatment) of SātS's vaibhaviyanarasimhakalpa within the framework of İS, I will firstly discuss some passages suggesting that Pāñcarātrika authors were familiar with re-working and re-using the texts. Then I will proceed to the brief characteristic of the texts in question, i.e. both SātS and İS, followed by a short analysis of their concept of initiation $(d \bar{\imath} k s \underline{a})$. After presenting their parallel 
passages, I will conclude with some cautious observations regarding the reasons for the omission of the vaibhaviyanarasimhakalpa section in the case of İS.

\section{How the samhitās of Pāñcarātra might have been Composed}

The Pāñcarātrika saṃhitās were regarded to be revealed by God himself and composed in the form of a dialogue, which was actually the divine revelation (Rastelli 2003, p. 1). Accordingly, their authors or compilers remain unknown to us: "they hide themselves completely behind the divine figures and sages whom they introduce as instructors and questioners" (Gonda 1977, p. 119). Therefore, "the catena of divine and prehistoric transmitters is the counterpart of the exact indications of the preceptors and ancestors of a commentator so often found in exegetical works: the guruparamparās guaranteeing the reliability of the tradition" (Gonda 1977, p. 119). Yet, as Gonda continues: "this does not however mean that the compilers are not committed to that which is taught in their books. They expound, as well as they can, the religious doctrines of their community, that is of the Pāñcarātra school of thought as handed down in a definite region and in definite milieus of which these authors are learned guides" (Gonda 1977, p. 119).

A passage found in JayS sheds some light on the features of text compilers and, possibly, copyists. One finds there the definitions of both the knower of a treatise (śāstrajña) and its preserver (śāstradhāraka) ${ }^{1}$ suggesting that among the followers of the tradition there were people responsible for knowing the doctrine as well as people responsible for reconstructing and maintaining the texts/manuscripts. The JayS 22.51cd-56ab reads: "[Characteristic of the knower of a treatise: ] Know that he [who] knows purānas, dharmaśāstras and Vaiṣnava itihāsas, [he who] would not only listen to the doctrine of Vedānta but also explains it, [he who] having discussed the reading of the lost words with their knowers, with effort and attentively keeps on refining the treatise (āgama), such [a person] is a knower of a treatise belonging to the Vaiṣnava tradition. [Characteristic of the preserver of a treatise: ] Know that he [who] having collected all treatises (ägamas) wherever they were with faith, then maintains them carefully meditating on Brahman, [he who] worships the seat of the treatise with the arghya-offerings, flowers etc., [he who] transmits [the texts] of the Vaiṣnavas and keeps away those of unprepared minds following other doctrines, such [a person] is a preserver of a treatise." By saying that through the reconstruction of the lost words the knower of a śāstra arranges the treatise or, in other words, makes it perfect, refines it (samskaroti), the text points most probably to the fact that those treatises, even though treated with the highest esteem, were, with time, subjected to reworking, modifications and manipulations. ${ }^{2}$

One of the aspects of changes that happened within the boundaries of Pāñcarātrika literature in the course of time seems to be the concept that the

\footnotetext{
${ }^{1}$ Also treated in Czerniak-Drożdżowicz (2003, p. 40; 2006/2007, pp. 228-229).

2 Among the reasons for such modifications one can enumerate not only religious factors but also changes in the social, political and economic situation of a given community. See Czerniak-Drożdżowicz (2006/2007, p. 9).
} 
particular younger texts are linked to the most respected ones. The best known passage on both the concept of mutual relations between the older and younger samhitās as well as the technique of composing the latter ones comes from the additional chapter of JayS called Adhikapātha (JaySA). The JaySA is relatively young, since it must have been composed after the time all the texts it mentions had been composed, including İS, PārS and the text which is traditionally linked to JayS itself, i.e. PādS. ${ }^{3}$ Here, for the first time within the scope of the Pāñcarātra literature the idea of a "basic" (mūla) text and its traditional commentary ( vyākhy $\bar{a})$ is openly expressed. In accordance with JaySA, the latter one is composed through borrowing to a certain extent the content of the former. Thus JaySA 1-8ab says that the whole corpus of Pāñcarātrika scriptures has been revealed by Nārāyaṇa himself. Out of these, the SātS, the PauṣS and the JayS are called the "three gems" (ratnatraya). They are regarded to be the essence of the teaching of the Săttvata [clan], to be secret, approved by learned men and to have emerged directly from the mouth of Bhagavān in their accomplished form. This means that they are neither defective nor too broad. The other scriptures, among them the so called commentaries (vyākhyāa), are said to be composed through filling them up with the essence coming out of the mouth of Bhagavān by adding, removing or keeping it. Their value depends, however, on the coexistence with the basic text ( $m \bar{u} l a)$, i.e. one of the "three gems". The texts are believed to function in pairs. JaySA $11 \mathrm{~cd}-12 \mathrm{ab}^{4}$ reads: "The wise one should know that the three treatises present one doctrine which can be fruitfully used, since it has the form of, respectively, basic text and commentary". The PārS is said to have descended in the form of $v y \bar{a} k h y \bar{a}$ in order to explain the meaning (vivrtyartha) of PaușS, İS has been caused to descend in order to explain the meaning of SātS and PādS is said to be the commentary (vyākhyāna) on JayS.

It has already been generally accepted that it was the particular idea of the author of JaySA to present the three vyākhyās/vyākhyānas as commentaries, even though in terms of structure they are not proper commentaries. ${ }^{5}$ Those vyākhyās are in fact independent, self-sufficient texts arranged in the same way as the rest of Pāñcarātrika saṃhitās, including the aspect of the unknown authorship. Nevertheless, most probably for the sake of a greater authority, they borrow more or less richly from the elder samhitās. Still, neither do the compilers of vyākhyās limit themselves to borrow from the particular samhitā ascribed to them by the author of

\footnotetext{
3 Architectural details of the Varadarāja Temple in Kāñcīpuram mentioned therein allow us to date it, contrary to the corpus of JayS, to the fourteenth century. See Rajan (1967, p. 73) and Rastelli (1999, pp. 52-53).

4 JaySA 11: mūlavyākhyānarūpatvād upajīvyam parasparam //11// tantratrayam idam vidyād ekaśāstram tathā budhah /

5 See Rastelli (1999, pp. 54-55), where the same portions of the JaySA are treated, too. In the context of Indian philosophical terminology, the terms vyākhyāna, vivrti consider usually the action of "commenting" by a commentator for the sake of establishing the proper meaning of a text commented upon by him.
} 
the additional chapter of JaySA, nor do the compilers of the rest of the known samhitās resign from that, which shows the conventionality of the concept presented in JaySA. ${ }^{6}$ The technique of re-using the older texts is not limited to the three so called commentaries, but it is visible throughout almost the whole corpus of Pāñcarātra. One can also observe a change in respect to the subjects treated: in the course of time, there is an internal trend to depict the tradition as fitting the brahmanical environment of South India and, in consequence, to betray much fewer tantric features.

\section{Sātvatasạ̣hitā versus İ́varasaṃhitā}

Let us turn to the case of certain borrowings between ĪS and SātS. It was already mentioned that as for the latter one, the redaction available to us was most probably composed in Kashmir, in the ninth century AD. In the case of ISS, there are still controversies regarding the time of its composition. However, all scholars agree that it must have been compiled in the South of India. Both Schrader (1995, p. 16) and Gonda (1977, pp. 54-55) propose to consider it the oldest samhitā among those of Southern Indian origin, but not earlier than the tenth century. According to Matsubara (1994, pp. 27-31), ${ }^{7}$ the text is much younger and should be dated at the fourteenth century, and its compiler must have been inspired by the older PārS. Nevertheless, as Matsubara continues, there must have been two variants of İS, the older and the younger one, out of which the latter one is now available, whereas the former one is known from quotations found in Yāmuna's (tenth century) Ägamaprāmānya.

If we compare the colophons of SātS and İS, both comprising 25 chapters, it turns out that in accordance with the changes which took place in the course of time, the former one focuses mostly on two subjects: the prominent role of different facets of the worship on vyūha and vibhava modes of God (2-6, 9-13) and, further, on the issues related to the initiation ( $d \bar{\imath} k s \underline{a})(16-23)$, whereas the latter one presents mostly the prescriptions connected with various aspects of temple practice. Its first section (2-9) regards the daily routine of temple priests, the second (10-15) regards the occasional festivals taking place throughout the year, the third (16-19, 21-22) regards the optional activities such as those performed in the context of the temple, including its building, furnishing, consecration as well as the vows (vrata) and initiation $(d \bar{l} k s \underline{\bar{a}})$. The additional fourth part (23-25) contains in turn the answers to six questions regarding the interests of professional priests (Smith 1975-1980, pp. 66-67).

In accordance with convention, the first chapter of ĪS contains the mythical story of the text's revelation (śāstrāvatāra). It is where the link with SātS is established and the

\footnotetext{
${ }^{6}$ For example, as for the first case, there are parallel passages between all three "gems" and PārS (Rastelli 2006). As for the second case, there are parallel passages between Śrīpraśnasaṃitā and SătS regardless of the fact that the former one is not believed to be a vyākhya of any older samhitā, see Padmanabhan (2006).

7 The thirteen lines of the text quoted under that title in Ägamaprāmānya (to be found in Narasimhachary 1976, p. 163) do not appear in the published version (Matsubara 1994, p. 28).
} 
Chart no. 1. Colophons of SātS and İS

SātS İS

1. Questions and answers (praśnaprativacana)

2. [no specific colophon]

3. The extraction of the mantra of a [deity] in vyūha [aspect] in sușupti [state] (sușuptivyūhamantroddhāra)

4. [no specific colophon]

5. [no specific colophon]

6. The worship of [a deity] of a fourfold nature (caturātmyārādhana)

7. The rules of vows (vratavidhi)

8. The rules of annual vows (samvatsaravratavidhi)

9. The internal worship of vibhava deities (vibhavadevatāntaryāga)

10. The [external] worship of vibhava deities (vibhavadevatārcana)

11. The rules of the offering and a fire pit (yāgakundavidhi)

12. The visualization of vibhava deities (vibhavadevatādhyāna)

13. The visualization of the deities with their weapons starting with ornaments (bhüṣaṇādyastradevatādhyāna)

14. The rules of wearing a pavitra (pavitrāropaṇavidhi)

15. The rules of the [festival] of bathing a pavitra (pavitrasnānavidhi)

16. The procedure [of mastering the mantra for the sake of] pacifying evil (aghaśāntikalpa)

17. The procedure of [mastering the mantra of] Narasimpha in vibhava form (vaibhaviyanrsimhakalpa)

18. The rules starting with the preliminary ceremonies of initiation (adhivāsadīkșāvidhi)

19. The rules of initiation (dīkșāvidhi)

20. The rules of consecration [of a person] (abhisekavidhi)

\section{$\overline{\mathrm{IS}}$}

1. The revelation of the text (śāstrāvatāra)

2. The rules of internal worship (mānasayāgavidhi)

3. The rules of the worship of the deities of the temple (vimānadevatārcanavidhi)

4. The rules of [the ceremony] ending with waving lights before an idol (nīrājanāntavidhi)

5. The rules of kindling fire and preparing food (bhojyāsanāgnikāryavidhi)

6. The rules beginning with the distribution to the ancestors and ending with the festival of śayana (pitṛsamvibhāgādiśayanotsavāntavidhi)

7. The rules of worshipping Lakșmī and Sudarśana (lakṣmīsudarśanārcanavidhi)

8. The rules of worshipping the deities of the retinue starting with Garuḍa (garuḍādiparivārārcanavidhi)

9. The rules starting with the characteristic of the deities of the doors and the accompanying [deities] (dvārāvaranadevatālakșaṇādividhi)

10. The rules ending with the great festival of raising the flag (mahotsavadhvajārohanāntavidhi)

11. The rules of the great festival (mahotsavavidhi)

12. The rules of the festival of half of a lunar month (pakșotsavavidhi)

13. The rules starting with the festival of half of a lunar month (pakșotsavādividhi)

14. The rules starting with the pavitra festival (pavitrotsavādividhi)

15. The rules of the act of causing a bath (snapanavidhi)

16. The rules starting with the consecration of the temple (prāsādādipratișthāvidhi)

17. The characteristic of the idol etc. (pratimādilakșaṇa)

18. The prescription for consecration [of an idol] (pratișthāvidhāna)

19. The rules of atonements (prāyaścittavidhi)

20. The greatness of Yādavācala (yādavācalamāhātmya) 
21. The rules of the prescriptions [for proper behaviour] (samayavidhi)

22. The rules of the various signs relevant to the one possessing the authority (adhikārimudrābhedavidhi)

23. The rules of the preliminary ceremonies of initiation (adhivāsadīkșāvidhi) [in fact rules on mantras]

24. The characteristic of an idol, the throne and the temple (pratimāpịthaprāsādalakșaṇa)

25. The rules of consecration [of an idol] (pratișthāvidhi)
21. The rules of initiation (dīkșāvidhi)

22. The prescriptions about the restrictions [for proper behaviour] (niyamavidhāna)

23. The rules of the extraction of the mantra (mantroddhāravidhi)

24. The characteristic of signs and the mode of visualization of Bhagavān (mudrālakșaṇabhagavaddhyānādiprakāra)

25. The characteristic of the fire pit and the offering ladle of sruk and sruva types and the prescriptions [regarding] the preparation of butter-offering (kuṇdasruksruvalakṣaṇahavihpākavidhāna)

prominent role of being both the essence ( $\mathrm{s} \overline{\mathrm{r}} \mathrm{r}$ ) of divine śāstras and the explanation of SātS (sātvatārthaprakāsikik) is highlighted. However, since the compiler of İS was influenced by the PārS's story, the way of expressing the relation between both texts is not his genuine idea. ${ }^{8}$ The verses considering the relation with SātS are inspired by the relevant passage of the PārS speaking about the connection of the latter with PauṣS: PārS 1.90-92ab ${ }^{9}$ uses the formulation arthopapādaka in this context.

The sage Nārada says (İS 1.47-53) ${ }^{10}$ : "Listen to what I am going to tell. Previously, Bhagavān Hari himself looked at those who desire the benefit for all people for the sake of favouring those who have abandoned the supreme dharma and wished to approach a mixed dharma, [and] even more (bhīyas) those who aspire at his abode [and] those who wish to reach faith and devotion. For the sake of showing favour towards [them] and for the sake of creating the ability for all varnas

\footnotetext{
${ }^{8}$ For details regarding the inspiration by PārS visible in the case of revelation stories of both texts see Rastelli (1999, pp. 80-84) and Matsubara (1994, p. 29).

9 PārS 1.90-92ab: pārameśvaraśastrānām sarveșām munipungava / sārabhūtam viśeșeṇa pauṣkarārthopapādakam //90// mūlavedānusārena chandasānuștubhena ca / lakșagranthena sarvārthakriyājñānopalabdhaye //91// sa me 'bravīn mahāśāstram pārameśvarasamjinayā / "O great sage! For the sake of teaching me all knowledge which has efficacy to be seized, he [Samkarșana] revealed to me the great śāstra called Pārameśvara, which is the essence of all śāstras [communicated] by Pārameśvara, which explains especially the meaning of Paușara[samhitā], [composed] in accordance with the Root Veda in anuștubh metre comprising one hundred thousands words."

${ }^{10}$ İS 1.47-53: śrūyatām abhidhāsyāmi sarvalokahitaișinah / puraivam bhagavān eva samālocya haris svayam //47// parityajya param dharmạ̣ miśradharmam upeyuṣām / bhūyas tatpadākāìkṣānām śrāddhābhaktī upeyușām //48// anugrahārtham varṇānām yogyatāpādanāya ca / tathā janānām sarveșām abhīṣtaphalasiddhaye //49// mūlavedānusāreṇa chandasānuṣtubhena ca / sātvatam paușkaram caiva jayākhyetyevam ādikam //50// divyam sacchāstrajālam tad uktvā sañkarṣan̄ādibhih / pravartayām āsa bhuvi sarvalokahitaișibhị̣ //51// evam divyāni śāstrāṇi śāṇ̦ilyo 'pi mahāmunih / sañkarșaṇād bhagavatah śrutvā adhyāpayan munīn //52// malayācalaniṣthāiś ca purā rāmasya cājñayā / prathamam sātvatam śāstrạ̣ samyag adhyāpitā mayā //53//
} 
as well as for the sake of realizing the goals desired by all people, he communicated the net of the divine true śāstras, in anuștubh metre and in accordance with the Root Veda (mūlaveda), starting with Sātvata-, Paușkara- and Jayākhya[saṃitā]. Then, he activated Samkarṣaṇa and others who desire the benefit for all people, [to teach His words] on earth. In the same way, also the great sage Sāṇ̣ilya having heard those divine śāstras from Bhagavān Samkarṣaṇa taught them to [other] sages. [Those who] were staying in the Malaya mountains previously have been taught correctly by me, with the consent of God Rāma, at first the śāstra [called] Sätvata."

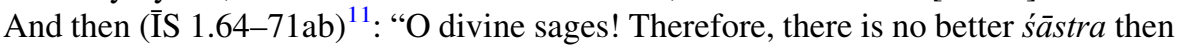
the divine Sätvata. Those beginning with Sātvata, Paușkara and Jayākhya are divine śāstras announced by Hari himself in accordance with the Root Veda for the sake of the benefit. These three śāstras, starting with Sätvata, are everywhere (vyāpaka), o best sages! Likewise, the three mantras starting with the eight-syllabled one (aștāksara), ${ }^{12}$ o wise ones! Thus, according to the prescriptions of the three texts (tantra), Hari is worshipped in Yādavācala, Śrīranga and Hastiśaila respectively. Among these divine śāstras, however, Sātvata is the greatest among the greatest. The God himself directly announced it and Lord Samkarṣana listened to him: How to characterize the greatness of this Sätvata, o divine sages! Thus, o the best of twice born! I will tell you about the tantra called Iśvara, which is the essence of the śâstras communicated directly by Iśvara, which explains specifically the meaning of Sātvata[saṃitā] (sātvatārthopapādaka) and has been heard from Saṃkarṣaṇa himself. Listen, o sages, with attention."

In addition, the mutual connection between $\overline{\mathrm{I} S}$ and SātS is similarly expressed in the last chapter of the former, where the text says that it elucidates the meaning of SātS (sātvatārthaprakāśika) (ĪS 25.213). ${ }^{13}$

Although one could expect that due to the traditional link between SātS and ĪS, it was the compiler of $\overline{\mathrm{IS}}$ who was primarily interested in the content of SătS; according to the information mentioned above (that is the fact that the siastrāvatāra of the İS has been influenced by that of the PārS), also the short summary of SātS found in İS 21.567cd-577ab appears to be borrowed from PārS 19.529-538. In both

\footnotetext{
11 İS 1.64-71ab: ato divyāt parataram nāsti śāstram munīśvarāh / sātvatam pauṣkaram caiva jayākhyam ca tathaiva ca //64// evamādīni divyāni śāstrāṇi hariṇā svayam / mūlavedānusāreṇa proktāni hitakāmyayā //65// sātvatādyam trikam caitat vyāpakam munisattamāh / yathā cāṣtākșarādīnām mantrānām tritayam budhāh //66// etat tantratrayoktena vidhinā yādavācale / śrīrañge hastiśaile ca kramāt sampüjyate harih // 67// eteșu divyaśāstreșu sātvatan tūttamottamam / vaktā sākṣād ìsvaro 'sya śrotā saṃkarșaṇah prabhuh // 68// kim varṇyate 'sya māhātmyam sātvatasya munīśvarāh / atas sākṣādīśvaroktaśāstrāṇāṃ dvijapunigavāḥ //69// sārabhūtạ̣ viśeșeṇa sātvatārthopapādakam / ìśvarākhyām idam tantram sākșātsaṃarṣaṇāc chrutam //70// sampravakșyāmi munayaḥ śṛnudhvam avadhānatah /

12 The three mantras are the six-syllabled (șadakșara), the eight-syllabled (aștākșara) and the twelvesyllabled (dvādaśäkșara) ones. Since İS teaches the eight-syllabled mantra, it is said to be the first one.

13 İS 25.213: sarvottamā saṃitā eșā sātvatārthaprakāśikā / nākhyeyā duștabuddhīnām abhaktānām janārdane //213// "O Janārdana! This saṃitā, which is the best one among all and elucidates the meaning of Sätvata[samhitā], should not be told to the bad-minded people who are not devoted to Viṣnu."
} 
cases the passage appears in the context of presenting the features of the mantrasiddhānta (one of the four doctrines into which the Pāñcarātra is traditionally divided), to which SātS belongs. It includes the outline of several subjects dealt with (in the same order) in SătS, among them the section on different forms of prādurbhāva deities; the section on the worship both in the heart-lotus and the lotusthrone, along with the worship of śaktis such as Lakșmī, Puṣti etc. as well as the worship of divine attributes such as conch and discus; the section on the initiation of Narasimha; the section on three initiations called vibhava, vyūha and sūkșma; the section on the four ranks of samay, putraka and others; the section on consecration; the section on the rules of religious and social behaviour (samaya); and the section on the order of the installation of idols, characteristics of mantras, mandalas, $m u d r a \bar{s}$, a fire pit and others. Additionally, the same passage is partly re-used in another chapter of $\overline{\mathrm{ISS}}$, i.e. İS 20, which praises the greatness of Yādavācala (yādavācalamāhātmya), the holy Vaiṣnava site linked to the tradition of SātS and İS. In that case, the verses presenting SātS as belonging to mantrasiddhānta are abandoned (İS 20.196-207ab). As a result, there might be two streams of borrowings: the re-use of the passage of PārS by the compiler of ĪS 21 (PārS $19.529-538=\bar{I} S 21.567 \mathrm{~cd}-577 \mathrm{ab}$ ) and the shortened version of the same passage re-used again within ĪS 20 with the same variants present in İS 21 (PārS 19.532cd$537=\overline{\mathrm{I} S} 21.571-575 \mathrm{~cd}=\overline{\mathrm{I} S} 20.198 \mathrm{~cd}-203$ ).

Chart no. 2. PārS 19.529-538 = ĪS 21.567cd-577ab

\begin{tabular}{|c|c|}
\hline PārS 19 & $\overline{\mathrm{I} S} 20$ \\
\hline $\begin{array}{l}\text { mantrasiddhāntasamjuñạ̣ } \\
\text { tajjāgradvyūhādimūrtinā / } \\
\text { samutkīrṇaṃ dvitīyasya } \\
\text { sātvatasya mahātmanaḥ //529// } \\
\text { tena pradyumnasaṃjnasya tena } \\
\text { turyātmano vibhoḥ / } \\
\text { tena vāgīśvarākhyasya tasmād } \\
\text { vīdyākhyavigrahe //530// } \\
\text { saṃkrāntam ca tatạ̣ paścād } \\
\text { rudrendrādityendravahniṣu / } \\
\text { tathaiva nāradādyeṣu devarṣin̄ām } \\
\text { gaṇeṣv api //531// saṃkrāntạ̣ } \\
\text { mantrasiddhāntam } \\
\text { bhedabhinnam anekadhā }\end{array}$ & $\begin{array}{l}\text { mantrasiddhāntasaṃjñam } \\
\text { tajjāgradvyūhādimūrtinā //567// } \\
\text { samutkīrṇạ̣ dvitīyasya } \\
\text { sātvatasya mahātmanạ̣ / } \\
\text { tena pradyumnasaṃjñasya } \\
\text { tena turyātmano vibhoh //568// } \\
\text { tena vāgīśvarākhyasya tasmād } \\
\text { dvīpākhyavigrahe / } \\
\text { saṃkrāntaṃ ca tataḥ paścād } \\
\text { rudrendrādityendravahniṣu // } \\
\text { 569// tathaiva nāradādyeșu } \\
\text { devarșin̄āṃ gaṇeșv api / } \\
\text { saṃkrāntạ̣ mantrasiddhāntam } \\
\text { bhedabhinnam anekadhā //570// }\end{array}$ \\
\hline
\end{tabular}




\begin{tabular}{|c|c|c|}
\hline PārS 19 & $\overline{\mathrm{I} S} 21$ & $\overline{\mathrm{I} S} 20$ \\
\hline 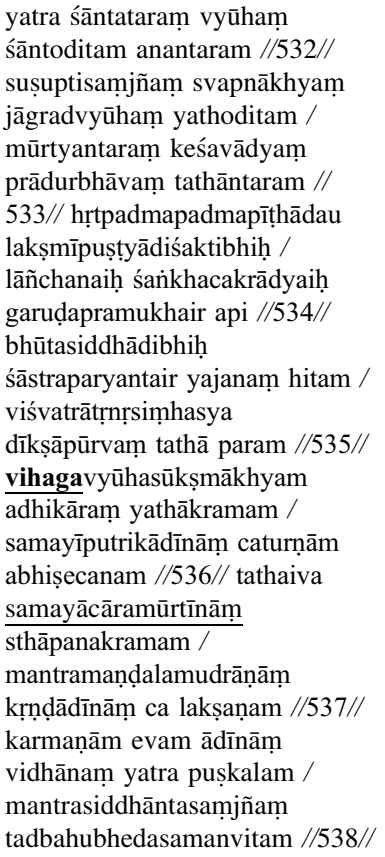 & 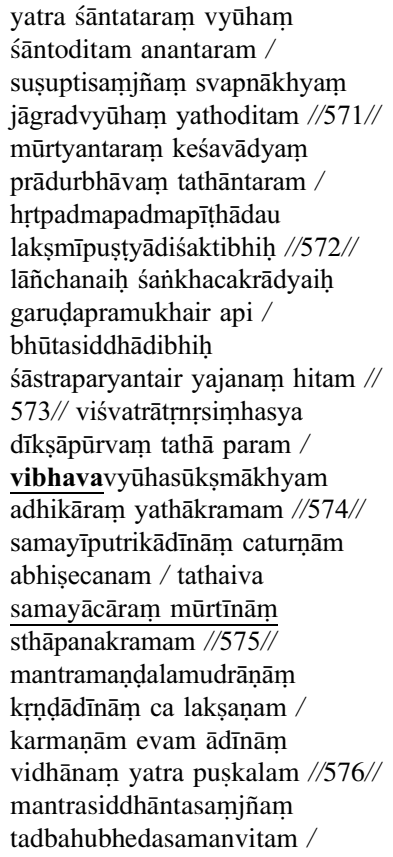 & 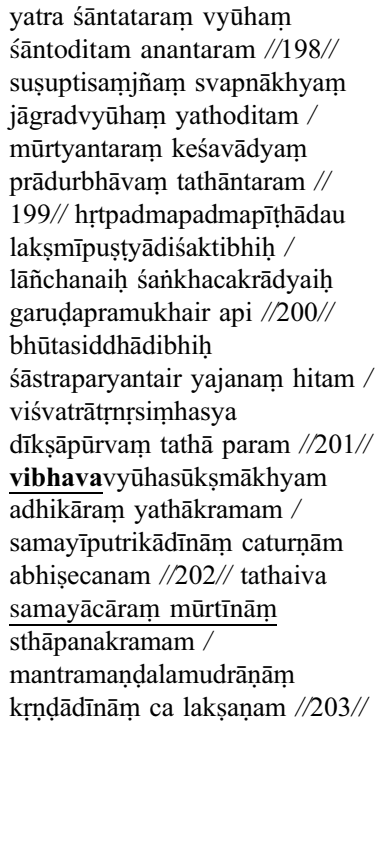 \\
\hline
\end{tabular}

PārS 19.532cd-537 = ĪS 21.571-576ab = İS 20.198cd-203 (modifications highlighted)

\section{Borrowings in the Case of Chapters on Initiation (dīkșā)}

Despite the conventionality of the idea proposed by the author of JaySA, there are in fact many parallel passages between İS and SātS. An interesting example of textual borrowings between them is the case of initiatory chapters. The compiler of IS reused the relevant portions of the latter to a great extent, however, as was already mentioned, this happened quite selectively. Whereas he rewrote many substantive passages from the consecutive chapters of SătS, others have been excluded by him. What is more, to provide his own chapters with an expected, logical structure, some new, original portions have been added by him. Therefore, at least in regard to the initiatory prescriptions, the account of $\overline{\mathrm{IS}}$ makes the impression of being a kind of an essence (sāra) of SātS, though at the same time it reflects the changes which took place within the tradition due to the historical circumstances.

In short, the SātS teaches the system of three initiatory paths. Each one of them is supposed to bear a particular result. In general, the highest $d \bar{l} k s ̦ \bar{a}$ (paradik $s ̦ \bar{a}$ ) provides liberation (kaivalya), the middle one (vyūhadīkșā) provides worldly pleasures (bhoga) together with liberation and finally, the lowest among them, namely vibhavadīkșā, provides first and foremost worldly pleasures (bhoga) (SātS 19.3-7). The three initiations of SātS differ in the type of initiatory mantra in the 
sense that a candidate, depending on his predisposition, might be initiated with the mantra belonging to the vibhava, vyūha or para aspect of Viṣnu. Nevertheless, there is only one initiatory pattern presented within the text, focusing on the initiation with the usage of vibhava-mantras. ${ }^{14}$ Therefore, we can presume that the procedures are similar in the case of all three $d \bar{\imath} k s ̦ \bar{a}$ s. In this connection each of them comprises the hierarchical entitlements of samayin, putraka, sādhaka and $\bar{a} c \bar{r} r y a$. However, before the initiation one should undertake the specific purification, or, if there is a need, cut off his previous religious affiliations by the means of an initiation with the help of the mantra of Narasiṃha. Then, as is explained in SātS 16, in order to check the readiness of the candidate to be initiated, the teacher observes him when he worships the mantra of Narasimha. As we could see from chart no 1, seven chapters of SātS deal with various initiatory prescriptions. These are: SātS 16 on the procedure [of mastering the mantra for the sake of] pacifying evil (aghaśāntikalpa), SātS 17 on the procedure of [mastering the mantra of] Narasimba in the vibhava form (vaibhavīyanrsimhakalpa), SātS 18 on the rules of the preliminary ceremonies of initiation (adhivāsadīkșāvidhi), SātS 19 on the rules of initiation (dīkșāvidhi), SătS 20 on the rules of consecration (abhiṣekavidhi), SātS 21 on the rules of the prescriptions of proper religious behaviour (samayavidhi), SātS 22 on the rules of various signs relevant to the one possessing the authority (adhikārimudrābhedavidhi), and SātS 23 on the rules of the preliminary ceremonies of initiation (adhivāsadīkșāvidhi) (but in fact on different kinds of mantras applicable during an initiation).

The $d \bar{\imath} k s \underline{a}$-related portions of $\overline{\mathrm{I} S}$ are, in turn, enclosed within two chapters: the 21st chapter, entitled "The prescriptions about initiation" (dīkșāvidhi), and the 22nd chapter, entitled "The prescriptions about the restrictions [for proper religious behaviour]" (niyamavidhāna). The former comprises many parallels with SātS 16 and SātS 18-20: three fourths of SātS 16 and almost the complete SātS 18, 19 and 20. The latter almost entirely (without introductory statements) corresponds to SătS 21 . The borrowed passages are taken systematically from the subsequent chapters of SătS (with the exception of SātS 17) and put in the order following the structure of SătS's exposition. Nevertheless, there is no reference to the source of borrowing. Most often, the re-used portions are joined together by means of short passages authored, possibly, by the compiler of İS. As for significant interferences in the structure of transmission of SātS (apart from occasional small modifications of, usually, single words or corruptions) one can enumerate the omission of SātS 17 containing the elaborate description of the procedure of worshipping the mantra of Narasimha in his vibhava form (vaibhaviyanarasimhakalpa) and the addition of the pañcasamskāra rite.

\footnotetext{
14 See SātS 19.169-177, where according to the account of vibhavadīkșā it says that in the case of vyūhadīkșā bïjas of four vyūhas should be applied in each rite, whereas in the case of brahmadīkșa (paradīkșā) it should be the first mantra ( $\bar{a}$ dyamantra) divided into six parts.
} 
Chart no. 3. Parallel passages between İS 21 and SātS 16.18-20

\begin{tabular}{|c|c|}
\hline$\overline{\mathrm{I}} \mathrm{S} 21$ & SātS 16.18-20 \\
\hline \multicolumn{2}{|l|}{$21.1-3 \mathrm{ab}$} \\
\hline $21.3 \mathrm{~cd}-28$ & 16.4-29ab (verbatim, with occasional small modifications) \\
\hline \multicolumn{2}{|l|}{$21.29 \mathrm{ab}$} \\
\hline $21.29 \mathrm{~cd}-30 \mathrm{ab}$ & 18.2 (verbatim) \\
\hline $21.30 \mathrm{~cd}-74$ & 18.4-48ab (verbatim, with occasional small modifications) \\
\hline \multicolumn{2}{|l|}{21.75} \\
\hline $21.76-91$ & 18.48cd-64ab (verbatim, with occasional small modifications) \\
\hline \multicolumn{2}{|l|}{ 21.92ab } \\
\hline $21.92 \mathrm{~cd}-98$ & 18.78-84ab (verbatim, with occasional small modifications) \\
\hline $21.99-105 \mathrm{ab}$ & 18.86-92 (verbatim, with occasional small modifications) \\
\hline \multicolumn{2}{|l|}{$21.105 \mathrm{~cd}$} \\
\hline $21.106-246 \mathrm{ab}$ & $18.93 \mathrm{~cd}-233$ (verbatim, with occasional small modifications) \\
\hline \multicolumn{2}{|l|}{$21.246 \mathrm{~cd}$} \\
\hline $21.247-283 a$ & 19.3-39a (verbatim, with occasional small modifications) \\
\hline $\begin{array}{l}21.283 \mathrm{~cd}-318 \\
{[1 . t \bar{a} p a, 2 . \bar{u} r d h v a p u n d r a]} \\
21.319-325[\text { nāma }]\end{array}$ & 19.39cd-46ab (verbatim, with occasional small modifications) \\
\hline $21.326-460 \mathrm{ab}$ & 19.46cd-180 (verbatim, with occasional small modifications) \\
\hline \multicolumn{2}{|l|}{$21.460 \mathrm{~cd}-464 \mathrm{ab}$} \\
\hline $21.464 \mathrm{~cd}-503 \mathrm{ab}$ & 20.2-40 (verbatim, with occasional small modifications) \\
\hline $21.503 \mathrm{~cd}-587$ & \\
\hline
\end{tabular}

As we can see, the passages taken over from SātS do not cover the whole content of İ 21. There are also visible additions reflecting the innovations which took place during the development of the Pāñcarātra tradition. In these terms, the significant portion appears just at the beginning of the instructions regarding the course of the proper initiation (corresponding to SātS 19). It discusses tāpa (branding) and 
Chart no. 4. Parallel passages between ĪS 22 and SātS 21

\begin{tabular}{|l|l|}
\hline İS 22 & SātS 21 \\
\hline $22.1-2$ & \\
\hline $22.3-22.38 \mathrm{a}$ & $21.3-38 \mathrm{a}$ (verbatim, with occasional small modifications) \\
\hline $22.38 \mathrm{~b}$ & \\
\hline $22.38 \mathrm{~cd}-62 \mathrm{a}$ & $21.38 \mathrm{~cd}-62 \mathrm{a}$ (verbatim, with occasional small modifications) \\
\hline $22.62 \mathrm{~b}$ & \\
\hline $22.62 \mathrm{~cd}-67 \mathrm{ab}$ & $21.62 \mathrm{~cd}-66$ (verbatim, with occasional small modifications) \\
\hline $22.67 \mathrm{~cd}$ & \\
\hline
\end{tabular}

ürdhvapundra (painting the mark) rites (ĪS 21.283cd-318), supplemented with the näman (naming) element. The passage regarding the latter one is again rewritten from SātS (ĪS 21.319-325= SātS 19.39cd-46ab) but placed in a new context. Those three rites, after adding two additional ones, i.e. mantra (conferring mantra) and $y \bar{a} g a$ (interpreted usually as offering an idol or teaching), together form an initiatory practice of five sacraments (pañcasamskāra). It is not attested in such a form in the oldest saṃitās of Pāñcarātra. ${ }^{15}$ The ceremony, optionally called samāśrayaṇa, is still performed nowadays in the South of India. As Raman claims, ${ }^{16}$ the pañcasamskāra rite, or at least some aspects of it, has been a marker of Vaișnava identity in the Tamil country at least since the ninth century AD. With time passing it took over a role of a basic initiatory rite endowing Śrivaișnavas with the competence to participate in the religious life of the community.

In comparison to SātS, the new element is also the portion at the end of İS 21 expressing again the different historical background. It discusses the features of the worship for oneself (svārtha) and for others (parārtha) (İS 21.504-512ab), continues with the greatness of Sanndilya and other sages important for the İS tradition (ĪS 21.512cd-558) and ends with the division into four Pāñcarātrika doctrines, so-called siddhāntas (ĪS 21.559-587).

\section{Why has the vaibhavīyanarasimhakalpa Section been Omitted?}

As we could see in charts no. 2 and no. 3, while preparing his own description of the $d \bar{l} k s \bar{a}$ practice, the compiler of $\overline{\mathrm{I} S}$ omitted the 17 th chapter of SātS. This happened

\footnotetext{
15 As Young summarizes, branding (tāpa) with a conch and discus was not specific for Pāñcarātra but associated with Vaiṣnavas in general. The earlier saṃhitās neither mention pañcasaṃskāra nor branding, although there is one exception. SātS 22.9 describes a samayin as having the body branded with cakra (cakrataptatanu), but as explained by Rastelli, "this could be a later modification of the text" (aber dies könnte eine spätere Modifikation des Textes sein, TĀK 3, s.v. tāpa). See Young (2006, p. 207).

16 On different aspects of this ceremony see Raman (2005, 2006).
} 
regardless of the fact that he re-used the other chapters of SātS on different aspects of initiation very extensively.

SătS 17 contains the account of a fully-fledged practice devoted to the mantra of Narasimha in his vaibhava form (according to colophon: vaibhaviyanarasimhakalpa). It might be divided into two broad but closely related sections: the former considers the practice of an ācārya preparing to confer the narasiṃhīdīkșa (SātS 17.3-148), and the latter considers the practice of an adept already initiated by the means of the mantra of Narasimha, including the account of magical powers (siddhi) he acquires (SātS 17.148-150cd, 153ab-456).

The contemporary interpreters of the procedure devoted to Narasimha as described in SātS (Smith 1975-1980; Gupta 1983; Hikita 1990, 1991, 1993; Hudson 2002, 2006; Carman 2006) follow to some extent the strategy of the compiler of IS in the sense of focusing mostly upon the information given in SātS 16 and SātS 1820 so that the narasimhadīkșa seems like a kind of preliminary rite. If we consider its function exclusively from the perspective of SātS 16, Hudson's proposal to interpret narasimhhadīkșa as a unique converting ceremony/purification seems the most convincing. Based on the Śaiva accounts of converting ceremonies, ${ }^{17}$ one can say that in the context of Hindu tantric traditions only after the converting rite comprising purifying ceremonies is accomplished, the proper initiation can be undertaken. Structurally it recalls the schema outlined in SātS 16, where after completing expiations in the form of prāyaścitta along with brahmakürca, one is, if there is such a need, supposed to undertake narasiṃhadīkșa to remove previously gathered serious sins or even religious affiliations. Being new-born, the adept is finally allowed to be regularly initiated into the tradition of SātS. ${ }^{18}$

However, in contradistinction to the content of SātS 16 as well as prevailing interpretations, the SātS 17 presents narasimhīìikșā as entitling the advanced adept to worship the mantra of Narasimh ha for the sake of realization of worldly aims (bhoga). In this connection, since the logical discrepancy between the 16th and 17th chapters of SătS is obvious, it makes us consider the content of the previous one as a kind of purposeful manipulation aiming at reformulation of the original meaning of the kalpatype ${ }^{19}$ ceremony devoted to Narasimha for the sake of establishing the unique cleansing ritual introducing even strangers, like nāstikas, into the tradition of Pāñcarātra.

Strikingly, it was the SātS 17 as a coherent, meaningful unit which has been neglected by the redactor of $\overline{\mathrm{I} S}$. That he must have been familiar with its content is suggested by the fact that many verses of SātS 17, most of them verbatim, can be found within the limits of İS's corpus. The size of these borrowings, adjusted to different contexts without any reference to the original source, ranges from half a śloka to nearly ten. All of them, however, come from the first section of SātS 17 presenting the activities of an ācārya preparing to perform narasimhadīkșa $\bar{a}$ so that,

\footnotetext{
17 There are at least two such examples: one is mentioned in the 27th verse of cāryapāda section of Mrgendrāgama (eighth century $\mathrm{AD}$ ) and the other in Somaśambhupaddhati dated from the eleventh century AD. For the latter one, called lingoddhāra, see Gengnagel (2010).

18 On the structure of converting ceremonies see Gengnagel (2010, p. 294).

19 In the context of Tantric Śaiva literature, the term kalpa refers to a text devoted to the worship of a single deity for the sake of realizing one's objectives by magical means, see Goudriaan (1981, p. 115) and Sanderson (2001, pp. 11-13).
} 


\section{Chart no. 5. Verses from SātS 17 throughout ĪS (modifications highlighted)}

\begin{tabular}{|c|c|}
\hline $\begin{array}{l}\text { 17.43cd-44ab } \\
\text { dakṣiṇottarahastābhyāṃ hṛdbījena vicintya ca// } \\
\text { sūryasomau tataḥ kuryād dravyadāhasamudbhavau / }\end{array}$ & $\begin{array}{l}\text { 3.30cd-31ab } \\
\text { dakṣiṇottarahastābhyāṃ hṛdbījena vicintya ca / } \\
\text { sūryasomau tataḥ kuryād } \\
\text { dravyadāhasamudbhavau // }\end{array}$ \\
\hline $\begin{array}{l}\text { 17.74-76ab } \\
\text { niṣtaptakanakābhaṃ ca sampūrṇānigaṃ } \\
\text { mahānutam / } \\
\text { ghoraśārdūlavadanam caṇdamārtaṇdalocanam// } \\
\text { saudāminīcayaprakhyair lomabhị paripūritam / } \\
\text { aruṇām bhojapatrābhạ̣ vajrādhikakaroruham// } \\
\text { calatphaṇî́sarasațam candrakoțiśatadyutim }\end{array}$ & $\begin{array}{l}\text { 20.250cd-252 } \\
\text { nișțaptakanakābhaṃ ca sampūrṇāngaṃ } \\
\text { mahātanum // } \\
\text { ghoraśārdūlavadanam caṇamārtāṇḍalocanam/ } \\
\text { saudāmin̄̄cayaprakhyair lomabhị̣ paripūritam// } \\
\text { aruṇām bhojapatrābhavajrādhikakareruham / } \\
\text { calatphaṇiśsarasaṭaṃ candrakoțitațitdyutim// }\end{array}$ \\
\hline $\begin{array}{l}17.77 \\
\text { pralayāmbudanirghoṣam udagirantam svavācakam / } \\
\text { yugāntahutabhugjvālāmaṇḍalāntarvyavasthitam // }\end{array}$ & $\begin{array}{l}20.253 \\
\text { pralayāṃbudhinirghoṣam udgirantam } \\
\text { svavācakam/ } \\
\text { yugāntahutabhugjvālāmaṇụalāntarvyavasthitam // }\end{array}$ \\
\hline $\begin{array}{l}\text { 17.78cd-79ab } \\
\text { divyagandhānuliptāngaṃ divyāmbaradharaṃ } \\
\text { tathā// } \\
\text { divyasragveșțanopetaṃ divyālañkāramaṇḍitam/ }\end{array}$ & $\begin{array}{l}4.92=20.257 \\
\text { divyagandhānuliptānigam divyāmbaradharam } \\
\text { tathā / } \\
\text { divyasragveșțanopetam divyālañkāramaṇḍitam// }\end{array}$ \\
\hline $\begin{array}{l}17.80 \\
\text { ratnakāñcanasanmuktāyuktayā vanamālayā/ } \\
\text { sabrahmasūtrayā caiva śobhitạ̣ parameśvaram// }\end{array}$ & $\begin{array}{l}4.94=20.256 \\
\text { ratnakāñcanasanmuktāyuktayā vanamālayā/ } \\
\text { sabrahmasūtrayā caiva śobhitam parameśvaram// }\end{array}$ \\
\hline 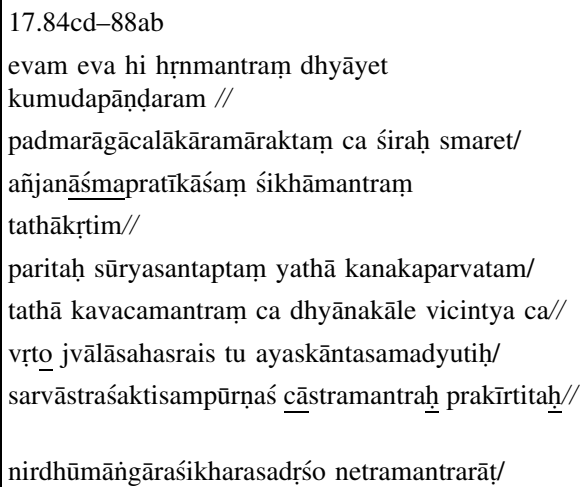 & 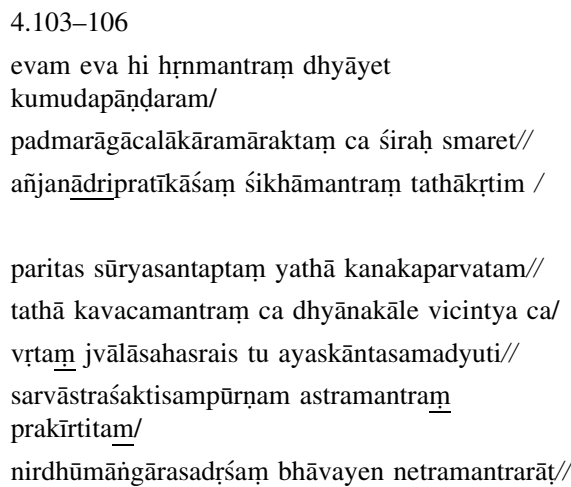 \\
\hline
\end{tabular}




\begin{tabular}{|c|c|}
\hline $\begin{array}{l}\text { 17.98-100ab } \\
\text { dhyātvā tretāgnirūpam tu dakṣināand añgulitrayam/ } \\
\text { spașțam ūrdhvaśikhạ̣ saiva jyeșṭhākrāntā } \\
\text { kanīyasī // } \\
\text { atho 'khilasvarūpaś ca dhvāntātīto 'gnirūpadhṛ/ } \\
\text { devo guṇatrayātītas tathā mārgatrayātigaḥ// } \\
\text { dharmaih sthūlatarair mukto yo 'yaṃ vyakto } \\
\text { dhiyārcitaḥ/ }\end{array}$ & 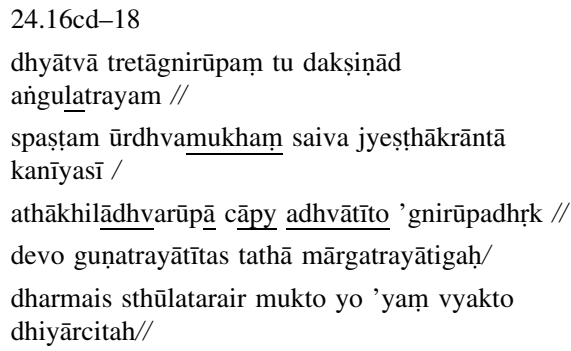 \\
\hline 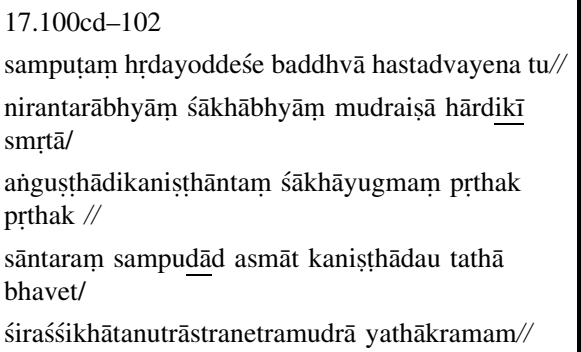 & $\begin{array}{l}\text { 24.21-23ab } \\
\text { sampuțam hṛdayoddeśe badhvā hastadvayena tu/ } \\
\text { nirantarābhyāṃ śākhābhyāṃ mudraișā } \\
\text { hārdradhīsmṛtā // } \\
\text { añgușṭādi kaniṣṭāntam śākhāyugmaṃ pṛthak } \\
\text { pṛthak / } \\
\text { sāntaraṃ sampuṭād asmāt kaniṣthādau tathā } \\
\text { bhavet// } \\
\text { śiraśśikhātanutrāstranetramudrā yathākramam }\end{array}$ \\
\hline $\begin{array}{l}17.104 \\
\text { svamantrayuktā cānyeșām arcitānāṃ } \\
\text { yathākramam/ } \\
\text { punaḥ punaḥ prayoktavyā hārdeyaṃ śirasā saha// }\end{array}$ & $\begin{array}{l}24.63 \\
\text { svamantrayuktā cānyeṣām arcitānāṃ } \\
\text { yathākramam/ } \\
\text { punaḥ punaḥ prayoktavyā hārdradhīś śirasā saha// }\end{array}$ \\
\hline $\begin{array}{l}17.107 \\
\text { yathāśakti japaṃ kuryāc chatam aṣṭādhikam tu vai// } \\
\text { ekaikaṃ hṛdayādīnāṃ sarveșām vihitam tv atha// }\end{array}$ & $\begin{array}{l}5.40 \\
\text { yathāśakti japaṃ kuryāc chatam aștādhikaṃ tu vāa } \\
\text { ekaikaṃ hṛdayādīnām sarveșām vihitam tv atha// }\end{array}$ \\
\hline $\begin{array}{l}\text { 17.110cd } \\
\text { kriyāñgatvān na doṣo 'sti anyathā tajjapam vinā// }\end{array}$ & $\begin{array}{l}\text { 5.41ab } \\
\text { kriyāngatvān na doṣo 'sti anyathā tajjapam vinā }\end{array}$ \\
\hline $\begin{array}{l}\text { 17.111cd-112 ab } \\
\text { vyasto guṇagaṇạ̣ șașṭhas tejo nāma guṇo hi yaḥ// } \\
\text { parasya brahmaṇaḥ so 'yaṃ sāmānyaṃ } \\
\text { sarvatejasām/ }\end{array}$ & $\begin{array}{l}\text { 5.86cd-87ab } \\
\text { vyāsto guṇagaṇāt șașthas tejo nāma guṇo hi yạ̣// } \\
\text { parasya brahmaṇas so 'yaṃ sāmānyạ̣ } \\
\text { sarvatejasām / }\end{array}$ \\
\hline
\end{tabular}

The text is reproduced from the editions given in References

for example, they do not deal with the procedures of the initiation itself or the issue of acquiring the magical powers (siddhi). What is more, they are scattered throughout the whole İS and re-used, again mostly verbatim, sometimes even twice, in its different chapters discussing various topics. Most of the minor modifications that appear in İS are not very significant or they are simply corruptions, but in some cases, as for example in the parallel passage of SātS 17.27cd (atha hastadvaye nyased dīptimad dvādaśákșaram) and IS 5.21cd (hastadvaye 'pi vinyasyed dīptam aștākșaram param), the compiler had to adjust the type of mantra in use: whereas in 
SātS's context it is the twelve-syllabled mantra of Narasimpha, in the context of İS it has been changed into the eight-syllabled mantra of Bhagavān.

This particular case of re-using the 17th chapter of SātS by the compiler of İS shows, on the one hand, to what almost unimaginable extent the notion of intertextuality was common for Pāñcarātrika authors, and, on the other, makes it tempting to consider the omission of SātS 17 as a meaningful section intentional for some reasons.

Are there any reasons for such lack of treatment of the procedure related to the Narasimha-mantra within İS?

In chart no. 3 we could see that in the case of SātS 16 the compiler of the İS restricts himself to quoting, word for word, only up to SātS 16.29ab. Significantly, that particular verse recommends conferring three regular initiations called vibhava, vyūha and sūkșma (SātS 16.29ab: vibhavyavyūhasūkșmākhyām dịkșām kuryād anantaram; İS 21.28cd: vibhavavyūhasūkṣmākhyām dīkṣām kuryāt tadantaram) immediately after performing narasimhīi $\bar{k} k s ̣ \bar{a}$ which removes past sins (SātS $16.26 \mathrm{ab}=\overline{\mathrm{I} S} 21.25 \mathrm{~cd}$ : kalmașasya vighātārtham nārasimnhīm mahāmate). Then, the exposition of İS smoothly continues with the portion taken from SātS 18 dealing with preliminary ceremonies of regular $d \bar{\imath} k s \underline{a}$. In such circumstances it seems that the idea of the redactor of IS 21 was most likely to present the initiation with the help of Narasimha-mantra simply in terms of purification to be taken before the proper initiation, quite similarly as it is implied by SātS 16 .

Yet, within the passages borrowed from SātS 16 (SātS 16.4-29ab = İS 21.3cd-28), a reference is made there to nāstikas etc., who by the means of the cleansing power of narasimhīìikșa may join the regular initiation of the vibhava, vyūha or para type. Afterwards, there are passages taken over from SātS 18 considering preliminaries to the dīkșā proper (adhivāsa) and the beginning of SātS 19 regarding the dìkșa itself but supplemented in its initial part with an account of the pañcasamskāra rite unknown to SătS (ĪS 21.283cd-325). According to Raman (Raman 2005, pp. 91-114), it was the pañcasamskāra rite which in certain Śrīvaiṣnava contexts "enabled a person to cross over from Śaivism to Vaiṣnavism”. In such circumstances, it might not be coincidental that at the beginning of the description of the regular initiation, borrowed in fact mostly from SātS instead of narasimhīìikșā, the compiler of İS provided an account of the pañcasamskāra rite. If we accept the interpretation of Raman, then both narasiṃhadīkșa and pañcasamskāra rites occur to have the similar function, i.e. the function of introducing strangers into the tradition.

However, it might also have happened that due to the general tendency, the compiler of ISS being aware of the actual content of SātS $17,{ }^{20}$ aimed at invalidating of

\footnotetext{
${ }^{20}$ It seems that at least the compiler of $\mathrm{AhS}$ was familiar with the actual function of narasimhakalpa, i.e. the function of providing a sādhaka with magical powers arising out of mastering the mantra of Narasiṃha. He does not quote from SātS but refers to it. The meaningful passage appears in the context of a teaching regarding magical amulets (yantra) meant for kings and the like to secure the kingship. AhS 27.31-33ab: sāttvatādișu tantreșu vihitenaiva cādhvanā / sudarśanasya mantrasya nārasiṃhasya vā mune //27.31// kalpaprayuktā vidhayah sarve caitasya samnidhau / bhavanti sakalāś caitatprabhāveṇa prayojitāh //27.32// tasmād yathoktamārgena pratișthāpyaitad arcayet / "O sage! The prescriptions related to the worship (kalpa) of the mantra of Sudarśana or Narasimha [should be performed] with the method [given] in Sãtvata and other tantras. In its [yantra's?] presence all of them become complete [if] performed with its power. Therefore, he should worship it having placed it according to the aforesaid way". On the vaibhavīyanarasiṃhakalpa in SātS see Dębicka-Borek (2013).
} 
the role of a sādhaka described therein. Such purposeful removal of the passages on sädhaka's practice would not be surprising if we take into account, on the one hand, the observations of Brunner regarding the general devaluation of sādhakas within Indian society (Brunner 1975), and on the other, the visible incoherence of the function of vaibhavīyanarasimhakalpa as presented in SātS 16 and SātS 17 respectively, which might have appeared problematic also to the compiler of İS when he decided to re-use SātS's passages on initiation. By neglecting the content of SātS 17, which discusses the particular methods of worshipping the mantra of Narasim̧ha applied by a sädhaka striving for particular siddhis, the compiler of İS 21 aptly omitted the logical ambiguity between the two chapters and therefore emphasized even more clearly the view presented by SătS 16. By doing so, he successfully led to the actual exclusion of the awkward results of narasimhīd $\bar{\imath} k s \underline{\bar{a}}$ in the form of creating a sādhaka aiming at the realization of bhoga with the help of magical powers. Yet, we cannot exclude the possibility that the omission of vaibhaviyanarasimhakalpa happened simply because such a procedure was well-known and, therefore, presenting it was redundant.

Open Access This article is distributed under the terms of the Creative Commons Attribution License which permits any use, distribution, and reproduction in any medium, provided the original author(s) and the source are credited.

\section{References}

\section{Original Sources}

Āgamaprāmānya = Āgamaprāmāṇya of Yāmunācārya . Ed. by M. Narasimhachary, (Gaekwad's Oriental Series, 160), Baroda 1976.

AhS = Ahirbudhnyasaṃhitā. Ahirbudhnya-Samnitā of the Pāñcarātrāgama . Ed. by M.D. Ramanujacharya under the Supervision of F. Otto Schrader. Revised by V. Krishnamacharya, 2 vols., (The Adyar Library Series, 4), Adyar 1986.

İS = İ́varasaṃhitā. İśvarasaṃitā Anantācāryais saṃsodhitā, (Śāstramuktāvalī, 45), Kāñcī 1923.

JayS = Jayākhyasaṃhitā. Jayākyasamhita. Crit. Ed. with an Introduction in Sanskrit, Indices, etc. by Embar Krishnamacharya, (Gaekwad's Oriental Series, 54), Baroda 1934.

Mrgendrāgama (Kriyāpāda et Caryāpāda), avec le commentaire de Bhaț̣-Nārāyanakanțha. Ed. by N. R. Bhatt, (Publications de l'Institut Français d'Indologie, 23), Pondicherry 1962.

PādS = Pādmasamnhitā. Padma Samhita. (Part I). Crit. ed. by Seetha Padmanabhan and R. N. Sampath. (Part II). Crit. Ed. by Seetha Padmanabhan and V. Varadachari, (Pancaratra Parisodhana Parisad Series, 3-4), Madras 1974, 1982.

SātS = Sātvatasamnitā. Sātvata-saṃhitā. With Commentary by Alaśinga Bhatța. Ed. by Vrajavallabha Dvivedī, (Library Rare Text Publication Series, 6), Varanasi 2001.

ŚrīprśnS = Śrīpraśnasaṃhitā. Śrīpraśnasaṃhitā. Ed. by S. Padmanabhan, (Rashtriya Sanskrit Vidyapeetha Series, 12), Tirupati 2006.

\section{Secondary Sources}

Brunner, H. (1975). Le sādhaka, personnage oublié du śivaïsme du Sud. Journal Asiatique, 263, 411-443. Carman, J. B. (2006). Illuminating the relation between Pāñcarātra and the early Śrīvaiṣnava community. In G. Oberhammer \& M. Rastelli (Eds.), Studies in Hinduism IV. On the mutual influences and relationship of Viśiștāâvaita Vedānta and Pāñcarātra (pp. 55-73). Wien: Verlag der Osterreichischen Akademie der Wissenschaften. 
Czerniak-Drożdżowicz, M. (2003). Pāñcarātra scripture in the process of change. A study of Paramasamhitā. Vienna: The De Nobili Research Library.

Czerniak-Drożdżowicz, M. (2006-2007). How to structure God's revelation-Some remarks about constructing tantric texts. Folia Orientalia, 42/43, 1-12.

Dębicka-Borek, E. (2013). Ritual Worship of the Narasiṃhamantra as Depicted in the Sātvatasaṃhitā. Cracow Indological Studies, XV, 167-207.

Dvivedī $2001=$ Sātvatasamhitā .

Gengnagel, J. (2010). Conversion or initiation. On the removal of the sectarian marks (lingoddhāra) in Śaiva Siddhānta. In A. Zotter \& C. Zotter (Eds.), Hindu and Buddhist initiations in India and Nepal (pp. 299-318). Wiesbaden: Harrassowitz Verlag.

Gonda, J. (1977). Medieval religious literature in Sanskrit. In A history of Indian literature (Vol. 2/1). Wiesbaden: Otto Harrassowitz.

Goudriaan, T. (1981). Hindu tantric literature in Sanskrit. In T. Goudriaan \& S. Gupta (Eds.), Hindu tantric and Śăkta literature (pp. 1-172). Wiesbaden: Otto Harrassowitz.

Gupta, S. (1983). The changing pattern of Pāñcarātra initiation. A case study in the reinterpretation of ritual. In R. Kloppenborg (Ed.), Selected studies on ritual in the Indian religions. Essays to D.J. Hoens (pp. 69-91). Leiden: Brill.

Hikita, H. (1990). Sāttvata Saṃhitā: An annotated translation. Chapter 17 (1). Soto-shū kenkyū kiyo, 21, 190-137.

Hikita, H. (1991). Sāttvata Saṃhitā: An annotated translation, Chapter 1 and 2. In Bukkyo bunkagaku ronshū Maeda Egaku hakase shoju kinen (pp. 578-546). Tokyo.

Hikita, H. (1993). Sāttvata Samphitā: An annotated translation, Chapter 18. Bulletin of the Faculty of Letters Aichi Gakuin University, 22, 1-26.

Hudson, D. D. (2002). Early evidence of the Pāñcarātra āgama. In K. A. Harper \& R. L. Brown (Eds.), The roots of tantra (pp. 133-167). Albany: State University of New York Press.

Hudson, D. D. (2006). The vyūhas in stone. In G. Oberhammer \& M. Rastelli (Eds.), Studies in Hinduism IV. On the mutual influences and relationship of Visisiștādvaita Vedānta and Pāñcarātra (pp. 125178). Wien: Verlag der Österreichischen Akademie der Wissenschaften.

Matsubara, M. (1994). Pāñcarātra Saṃhitās \& early Vaiṣnava theology. With a translation and critical notes from chapters on theology in Ahirbudhnya Samhitā. Delhi: Motilal Banarsidass.

Narasimhachary $1976=$ Agamaprämānya .

Padmanabhan $2006=$ ŚrīprśnS.

Rajan, K. V. S. (1967). Kaustubha Prāsāda-New light on Jayākhya tantra. Journal of the Oriental Institute of Baroda, 17, 71-85.

Raman, S. (2005). Samāśrayaṇa in Śrīvaiṣnavism. In J. Gengnagel, U. Hüsken \& S. Raman (Eds.), Words and deeds. Hindu and Buddhists rituals in South Asia. Ethno-Indology. Heidelberg Studies in South Asian Rituals (Vol. 1, pp. 91-114). Wiesbaden: Otto Harrassowitz.

Raman, S. (2006). Initiation and conversion in Medieval South India: pañcasaṃskāra as historical practice in the Śrīvaiṣnava Post-Rāmānuja hagiographical literature. In G. Oberhammer \& M. Rastelli (Eds.), Studies in Hinduism IV. On the mutual influences and relationship of Visisțtâdvaita Vedānta and Pāñcarātra (pp. 263-286). Wien: Verlag der Österreichischen Akademie der Wissenschaften.

Rastelli, M. (1999). Zum Verständnis des Pāñcarātra von der Herkunft seiner Saṃhitās. Wiener Zeitschrift für die Kunde Südasiens, 43, 51-93.

Rastelli, M. (2003). http://ikga.oeaw.ac.at/Mat/rastelli_ekayanaveda.pdf. Accessed 12 June 2014.

Rastelli, M. (2006). Die Tradition des Pāñcarātra im Spiegel der Pārameśvarasaṃhitā. Wien: Verlag der Österreichischen Akademie der Wissenschaften.

Rastelli, M. (2007). The 'Pāñcarātra Passages' in Agnipurāna 21-70. In D. Goodall \& A. Padoux (Eds.), Mélanges tantriques à la mémoire d'Hélène Brunner. Tantric studies in memory of Hélène Brunner (pp. 87-229). Pondicherry: Institut Français de Pondichéry.

Sanderson, A. (2001). History through textual criticism in the study of Śaivism, the Pãñcarātra and the Buddhist Yoginītantras. In F. Grimal (Ed.), Les sources et le temps. Sources and time. A colloquium, Pondicherry, 11-13 January 1997. Pondicherry: École Française d'Extrême-Orient (pp. 1-47).

Schrader, F. O. (1995). Introduction to the Pāñcarātra and the Ahirbudhnya Saṃhitā. Madras: The Adyar Library and Research Centre.

Smith, H. D. (1975-1980). A descriptive bibliography of the printed texts of the Pāñcarātrāgama (2 vols.). Gaekwad's Oriental Series, 158 and 168. Baroda: Oriental Institute. 
TĀK = Goodall, D. \& Rastelli, M. (Eds.) (2013). Tāntrikābhidhānakośa, III. Wien: Verlag der Österreichischen Akademie der Wissenschaften.

Young, K. K. (2006). Brāhmaṇas, Pāñcarātrins, and the formation of Śrīvaișṇavism. In G. Oberhammer \& M. Rastelli (Eds.), Studies in Hinduism IV. On the mutual influences and relationship of Visișțāadvaita Vedānta and Pāñcarātra (pp. 179-261). Wien: Verlag der Österreichischen Akademie der Wissenschaften. 